\title{
映像作品を利用した異文化理解のための日本語教育 \\ Japanese Language Education for cross-cultural \\ understanding through Films and TV Dramas
}

門脇 薰

摂南大学

\section{1. はじめに}

現在のグロ一バル時代において、外国語を学習する必要性及び意義がますます高ま っている。外国語を学ぶということは、ことばとその目標言語の文化を学ぶことであ るということは、広く言われている。言語教育の近年の傾向としてスタンダードが注 目されているが、アメリカのナショナル・スタンダーズにおける 5 C (Communication, Cultures, Connections, Comparisons, Communities)、及びヨーロッパの共通参照枠 （CEFR）においては複数言語主義・複数文化主義が掲げられ、言語教育と文化とは切 り離せないものとして言及されている。また、国際交流基金の日本語教育スタンダー ドにおいても「相互理解のための日本語」を基本理念として異文化理解の要素が考慮 されている。

日本語教育においては、日本語学習者は、日本国内では文化庁の 2011 年の調査によ ると約 12.8 万人、海外 ${ }^{1}$ では国際交流基金の 2009 年の調査によると約 365.1 万人であ り、圧倒的に「海外で外国語として日本語（Japanese as a Foreign Language :JFL)」 を学ぶ学習者が多い。

特に JFL 環境では、生の日本語に触れる機会が限られるため、日本語の授業で日本 語による映画やドラマ等の映像作品が利用されることが多い。しかし、日本語指導に あたる多くの教師に利用され、その有効性が認識されながらも、各教師が現場で個別 に利用するにとどまり、具体的に教育実践が教師間で共有されているとは言い難い。

本稿では、異文化理解の観点から映像作品を利用した授業について、これまでの先 行研究を概観し、海外における映像作品利用の実態について韓国を中心に述へ、、更に 筆者の実践事例を挙げ、その具体的な授業デザイン及び可能性について考察する。

1 本稿では「日本国外」の意味で使用している。 


\section{2. 異文化理解と外国語教育}

異文化理解については、様々な定義がなされているが、ここでは単に知識を理解す るという一方的で受け身の知識伝達ではなく、自文化と異なる文化について理解し、 文化相対主義の立場から多様な価值観を受け入れ、それに基づいてコミュニケーショ ン行動がとれるこどのように、広くとらえている。

塩澤 (2010) では、外国語の授業で扱う文化要因をコミュニケーションにおける有効 性という観点から次のように分類している。

(1) コミュニケーション・スタイル・ストラテジー

(2) 周辺言語

(3) 非言語コミュニケーション

（4）価值観とそれに基づく行動パターン

（５）生活習慣と社会機能

（6）情報文化と達成文化

例えば、（1）は会話をどのように始め、終結するかというようなコミュニケーショ ンの進め方、（2）はあいら゙ちの打ち方や沈黙、（3）は表情やジェスチャー、（4）は 集団之個人、時間、空間等に対する価值観、（5）は生活スタイルやマナー、（6）は 地理的・歴史的情報や美術・文学等が含まれる。これらを教師が講義形式で説明する ことも可能であるが、やはり映像を用いて具体的に提示することによって、学習者の 理解が一層深まると考えられる。したがって、上記（1）から（6）を授業で扱うに は、実際のコミュニケーションの場面を教室で再現可能な映画・ドラマ等の映像作品 を利用することが有効である。

また、外国語（目標言語）を通して異文化理解を促す方法として、学習のプロセス を考えた場合には、「(1)認知学習」及び「(2)体験学習」の二つに分けられる。認知学習 とは、資料を読んだり、説明を聞く等して知識を得ることであり、体験学習とは、実 際の社会生活で遭遇する場面を疑似体験したり、実際に体験する方法である。「異文化 を理解する」とは、異なる文化についての知識を一方的に得ることだけではなく、あ る場面において適切な行動が取れるようになることが重要である。それには教室での 授業において、教師が学習者に知識を伝達するだけではなく、様々な媒体を使い、異 文化を体感させる必要がある。

2 塩澤 (2010) p. 29 参照。 
Fowler \& Blohm（2004）では、異文化トレーニングの学習活動及び手法として、 $\lceil$ Lecture, Written matarials, Computer-based training, Critical incidents, Simulations and games, Role Play, Culture assimilator (p 79)」等を挙げている が、その中に映像作品（Film）を媒体として利用することが言及されている。したが って、教室において異文化体験を促すために、映像素材を利用した授業デザインが一 つの方策として考えられるであろう。それによって、教室内に目標言語の状況・場面 を作り出し、文化的な要素を学ぶ場を作り出すことが可能になるのである。

次に具体的にどのように外国語教育で利用されているかについて先行研究を概観す る。

\section{3 映像作品を利用した外国語教育}

\section{1 英語教育における異文化理解のための映像作品の利用}

日本における英語教育は、海外における日本語教育と同様の外国語環境（EFL： English as a Foreign Language )にある。映像作品を利用した英語教育研究及び授業 実践が行われており、異文化理解のため映像作品を利用した授業実践も数多く見られ $ろ^{3}$ 。

福永（1995）は、「民族・人権・環境・平和」のような問題を英語教育で扱うグロー バル教育（Global Education）の必要性を指摘し、その教育において「難解な内容を やさしく学べる教材」が映画であるとしている。塚越（1995）では、映画『ゴースト』 を素材にし、「異文化への気づき」を促すための指導には映画を利用することが有効で あると述べている。また、高瀬（1998）は、アメリカ文化分析といら視点から映画の 教材としての可能性を探った研究であり、異文化理解のための映画分析基準を設定し、 映画『ある愛の詩』を分析している。その他、新藤（2003）は、映画のシーンを観察 させ、自文化（自己）と異文化（他者）に対する複眼的な気づき、カルチュラル・ア ウェアネス（cultural awareness）を導く異文化トレーニングの実践が報告されてい る。

これらの報告は実践報告であり、必ずしも実証的な実験結果による映像利用の効果 とは言えないが、英語教育においては、特に異文化理解を目的として、映像作品を利 用した様々な授業が行われていることがわかる。

3 映像英語教育学会が発足され、全国大会・支部大会等の研究会の開催、及び教材制作がなされて いる。 
また、日本の英語教育においては映画を利用した教材が非常に多く出版されている が、異文化理解のための教材も作成されている。アメリカの文化を紹介した『映画で 学ぶアメリカ文化』（八尋編 1999）では、100 のテーマを設定し、日本人学習者を対象 にアメリカ文化を日本語で解説している。

次に日本語教育における映像作品の利用について述べる。

\section{2 映像作品を利用した日本語教育}

これまで映像を利用した日本語教材の開発及び研究が行われており、その効用も論 じられている（城生 2002）。日本語教育映画では、文型や表現に伴う非言語行動や文 化を提示する手段として『日本語教育映画 基礎編』、日本語教育映像教材 中級編』

(国立国語研究所日本語教育センター1974～1990)、『ヤンさんと日本の人々1』（国際 交流基金) 等が作成されている。また、東京外国語大学では、日本の地理『食卓から日 本が見える』（1993 年制作）、留学生のための現代社会『憲法と日本人の生活』(1991 年制作）という映像を日本事情の授業のために制作している（藤森・中村 2001）。

本稿では、このような教育用に作成された映像教材ではなく、主に一般に公開され ている日本映画やドラマ等の映像作品を生の素材として利用した日本語教育の可能性 について考察している。というのは、近年海外でも日本の映画・アニメ・マンガなど に対する関心が広がっているからである。ダグラス・マックレイは「Japan’s Gross National Cool」4でクールな日本の映画・アニメ等のポップカルチャーが海外の若い 人達に多大な影響を与えていると述べている。実際に教育現場で接する留学生や、海 外で日本語を学習する人の中には日本の映画・アニメ・マンガ等に動機づけられ学習 を始めた人も少なくない。特に海外の学習者の約 6 割を占める初等教育・中等教育の 日本語教育においては、これらが学習動機に非常に強く結びついていることは否定で きない。

このような国内外の動向により、2006 年 1 月には全国日本語教師養成講座協議会主 催により、日本の映画・アニメ・マンガ等の日本のサブカルチャーと日本語教育につ いて考えるシンポジウムが開催された。また、同年 5 月の日本語教育学会春季大会シ ンポジウムでは「映画・アニメ・マンガー日本語教育の映像素材」、8 月の文化庁の日 本語教育大会では「マンガの活用」がテーマに取り上げられており、近年日本の映画・ アニメ・マンガといった素材を利用した日本語教育が非常に注目されている。

4 フォーリンポリシー (2002) より。 
映像作品を利用した日本語授業実践の報告としては、数は限られるが、次のような ものが挙げられる。下條（1997）では、中級クラスにおいて映画『シコふんじゃった。』 を利用した授業について報告されている。また、坂根（1998）では、『Shall we ダン ス?』を用いた教材開発とその教材を使用して行った授業の報告がなされている。窪 田（2002）は、映画や TV ドラマの日本語授業における効果的な利用方法として、映画 のデモ用の映像を作成して視聴すること、読書ノートのように「テレビドラマノート」 を作成することを挙げている。また、教師が映画の選定がしや寸いように、授業で利 用可能な映画の場面をまとめた「日本語教育のための映画カタログ」を作成すること を提案している。また、西隈（2006）ではアニメ『となりのトトロ』『あたしんち』の 理解と利用例を具体的に挙げている。

映像作品を利用した教材は、著作権の問題があり限られているが、次のようなもの が見られる。日本語教育学会（1995）では、映画『釣りバカ日誌』を使ったマルチメ ディア日本語教育教材の開発がなされている。また、鮎澤・加藤（1995）では、アニ メ『となりのトトロ』を素材に日本人の言語行動を教材化している。嵀田編（2004） の『映画でジャパニーズ』は、30 本の映画を選び、それらの映画について台詞や文化 的な解説がなされており、教材としてこのように市販化されたのは日本語教育におい て画期的であった。その後、更にカルチュラルスタディーズ等の内容も織り込まれた 『映画で日本文化を学ぶ人のために』(窪田編 2007) が続いて日本国内で出版された。 その他、国際交流基金シドニー事務所（2011）では、映画『しあわせ家族計画（Happy Family Plan)』を利用した DVD 教材が作成され市販化された。ホームページで教師及 び学習者支援のための解説がなされている5

以上のように、日本国内外で日本語教育においても、映画やドラマ等の映像作品を 活用した授業実践が実際に行われていると言える。しかしながら、日本語指導にあた る教師にも映像作品は有効なリソースであると認識されており、実際に授業で利用さ れているにも拘わらず、それらを利用した日本語教育の実践及び研究報告は、非常に 限られている。英語教育と比較してみた場合、日本語教育においては映像作品を利用 した教育実践について活発に議論がなされてはおらず、この分野の研究が進んでいな いことがわかる。

5 http://www. happyfamilyplan. com/ 
日本の映像作品の使用にあたっては、著作権の問題をクリアすることが困難なため、 英語の映像作品とは異なり、教材開発や教材作成が行いにくいということが考えられ る。しかし、前述のように特に、生の日本語に接する機会が限られている海外の日本 語学習者にとって、日本の映像作品を利用して日本や日本語に触れることは有効な学 習方法の一つであるため、海外の日本語教育における映像作品利用のニーズは高いと 考えられる。

国立国語研究所の「日本語教育の学習環境と学習手段に関する調査研究」の海外調

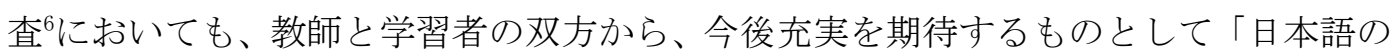
映画」が多く挙げられており、海外における映画のニーズが高いことがわかる。

海外の日本語教育において映画を取り入れた実践には次のような報告がある。

牧野（2008）は、アメリカの大学にて 映画『千と千尋の神隠し』を主教材とする日 本文化教育を積極的に行っている。「アニメ世界各国に自然に広がったものでこれを 利用しない手はない(p.64)」と述心、アニメを積極的に利用する理由を「広く、深く 越境した文化を利用することによって学習者の動機を高める」「言語が文化に密着して いる」「言語の脈絡化が作りやすい」「想像的思考を促す」「日本語の複雑さと面白さを 教えることができる」等と挙げている。

また、宮副・吉村（2005）では、日本と香港の大学生が、映画『Love Letter』また は『ウォーターボーイズ』を視聴し、日本社会・文化に関わる意見を電子メールで交 換するという活動が報告されている。また、梁（2006）では、日本と香港の大学院生 が映画『お受験』『Shal1 we ダンス?』『G0』を視聴しヴァーチャルで討論会を行うと いう授業デザインがなされている。

このように海外では映画を利用した日本語教育実践が行われており、上記以外にも世 界各地で実践されていると考えられる。しかし、その実践内容が教師間で十分に共有 されているとは言えず、各国・地域における映像作品を利用した日本語教育の詳細に ついて把握することは難しいのが現状である。

以上、映像作品を利用した日本語教育の先行研究について述べたが、実際に海外の 日本語教育においては、具体的によ゙のように映像利用がなされているのであろうか。

次に、韓国の例を中心に筆者が行った実態調査について述べる。

6 国立国語研究所『平成 15 年度日本語教育の学習手段に関寸る調査研究 韓国アンケート調査集 計結果報告書』より。 


\section{4. 海外における映像利用の実態}

海外の日本語教育における映像利用の実態について、門脇（2006）では、日本語学 習者数世界一を誇る韓国において、日本の映像作品の利用について調查した結果を報 告している。

\section{1 韓国の日本語非母語話者教師対象の調査}

韓国の中等教育の韓国人教師 45 名を対象にアンケート調查（2006 年実施）を行っ た結果、「自分自身が日本語を学習したときに映画を利用した経験がある」と答えた教 師が $82.2 \%$ あり、「日本語授業で映画を利用した」教師は $86.7 \%$ という結果であっ た。映画を利用した教材や授業のニーズが学習者(初〜上級レベル) 及び教師の双方か らあることがわかる。

映画を利用した授業の利点として、回答が多かったのは次の(1)〜(3)である。

(1)生の自然な日本語に触れることができる

(2)映像があるので理解度が高まる

(3)譼場感があるので興味を引く、場面から日本文化がわかる

やはり、JFL 環境である海外の中等教育では、(1)のように教科書の日本語以外で生 の自然な日本語を使う場面を設定する方法として映像作品が利用されていることがわ かる。

また、映画を利用した授業の困難点として、

(1)日本語のスピードが速すぎる

(2)授業の準備が大変

(3)映画を利用して作成されたいい教材がない

という点が挙げられた。中等教育の学習者は初級前半レベルであるため、(1)の回答の ように映像作品で使われている日本語のスピードが学習者にとって速いということは、 主に映像作品を聞き取り教材として利用していることがわかる。また、(2)に見られる ように、教師は映像作品を利用した授業準備を負担に感じていることが窥える。

その他、映画を利用した授業についての自由回答では、次のようなコメントが得ら れた。

・学習者の学習動機や日本文化一の関心が高まる。

・映像があるので生きた教育になる、やさしく覚えられる。

・学習内容が多样化される。

・いいと思うが、評価がしにくい。授業で使う機会を作るのが難しい。 
以上の結果より、教師は映画を利用した教材や、効果的な利用方法、具体的な教え 方について知りたがっており、教材や指導書があれば積極的に利用したいと思ってい る。しかし、海外では日本の映画や情報が入手しにくく、教材作成が難しいというこ とがわかった。

\section{2 韓国における映像作品を利用した日本語授業}

韓国の日本語教育現場において実際にどのように映像作品を利用した日本語授業が 行われているか調査するために日本語教育機関を訪問し（2006 年 3 月）、授業観察及 び教師へのインタビュー調查を行った。

以下に日本語教育機関別にまとめる。

\section{(1) 高校}

韓国の高校では、第 2 外国語として日本語が教えられている。筆者は韓城高校の朴 ユンウォン先生の高校を訪問し授業観察を行った。韓国の高校では検定教科書が使わ れているが、授業はパソコンが複数台設置された教室で行われ、授業中は教師が作成 したパワーポイント教材及びワークシートを使用していた。スクリーン及び各テーブ ルのパソコンに映し出された映像の視聴を中心にした授業であった。教師が様々な映 像を収集及び編集し、学習者は複数の映画やドラマ等の場面を部分的に視聴していた。 映像収集にあたっては、韓国の高校教師会（Japanese Teachers Association）のネッ トワークを利用し、教師会の教師達と積極的に映像作品の内容、編集技術について情 報交換しているとのことであった。日本語教育のリソースの共有について教師間協働 が非常にうまくなされている例である。

(2) 日本語学校

韓国の大手の民間日本語学校である「時事日本語学院」では、アニメ・ドラマに特 化したクラスが開講されている。そのクラスを担当している崔大立先生の授業では、 ドラマ『野ブタをプロデュース』を視聴していた。独自に作成したドラマのシナリオ 及び文法や表現を韓国語で解説したプリントが教材であった。特に毎月最近の新しい 映像作品を見ることができるため、当日本語学校において人気の高いクラスである。 その他のアニメのクラスでは、夜のクラスに会社員や学生等と一緒に小学生が受講し ていた。日本に長期滞在していた帰国子女の生徒で、日本語を忘れないためにアニメ で日本語を学んでいるということであった。年少者が日本語学習を継続する手段とし て、アニメやドラマが強く関わっていることがわかる。 


\section{(3) 大学}

同徳女子大学校では、日本語教育主専攻コースが設置されており、4 年生を対象に した「映像日本語演習」という授業科目が開講されている。尹福姫先生が担当するそ の授業では、グループ毎に映画を選んで視聴し、映画・言語表現・文化に関する内容 を発表し、その後クラスでディスカッションするという授業デザインがなされている。

授業で利用した映画は次のとおりである（尹 2008）。

(1) Love Letter、Shall We ダンス?、鉄道員、シコふんじゃった、踊る大捜査線、 GO ウォーターボーイズ、四月物語、サトラレ、東京日和、スウィングガール ズ、座頭市、下妻物語、花とアリス、電車男、嫌われ松子の一生、メゾン・ド・ ヒミコ、Always 3 丁目の夕日

(2) となりのトトロ、千と千尋の神隠し、耳をすませば

(3) 東京物語、キューポラのある街

最新の映画だけではなく、1950 年代、80 年代、90 年代に制作された映画も利用さ れていることがわかる。尹先生は、映画は日本語学習のみならず、日本文化を知るう えで無限の可能性をすばらしい教材であることを強調しており、講義中心の教師主導 の授業でなく、映画を題材とした学習者の発表を中心とする授業を提案している（尹 2008)。

以上、韓国における映像作品の利用について実態を調査した結果について述べた。 韓国の日本語教育においては、積極的に映像作品が利用されていることがわかった。

\section{5. 異文化理解のための日本語教育実践}

以上、英語教育及び日本語教育における映像を利用した教育実践の事例を挙げたが、 教師が映像をどのような目的で、どのように利用し、どのような授業を行うかという 授業デザインが重要である。本章では具体的に筆者の実践事例を挙げる。

\section{1 映像作品を利用した「日本事情」クラスの授業デザイン}

日本の大学における外国人留学生対象の授業に「日本語・日本事情」という科目が 設定されている。日本語の授業で、日本の文化を扱う「日本事情」の授業では、従来 教師が学習者に日本の歴史・社会・文化等について知識を与えることが中心であった。 これは客観主義の教育観による一方的な知識注入型の教育方法である。

その後、文化というものを固定化して捉え日本への同化を促す、従来型の日本事情 の教育が批判され、新しい日本事情教育のあり方が議論されるようになった 7 。

7 『21 世紀の「日本事情」一日本語教育から文化 リテラシーへ』創刊号 (1999) 
筆者は、「日本事情」の授業において構成主義の教育観に基づき映像作品を視聴して 様々な活動を行う授業デザインを試みた。一方的に教師が日本の文化について説明す るという形式だけではなく、「学習者による観察や対話を通して考察し、授業の参加者 がお互いに学び合う」ことを重視した。

構成主義の教育観とは、久保田（2002）は次のように述べている。

・知識は個人的体験・文化と切り離せない。それぞれ違った形で世界を理解する。

・学習者が主体的に学習活動に参加し、知識を構築する。

・学習は共同体の中での相互作用を通じて行う。

そして、学習は社会的に構成された対話的過程であると考え、学習者が主体的に関 わっていくには対話が重要であるとしている。

このような構成主義の教育観により、筆者らは映像作品を利用した対話を重視した 日本語授業の実践研究を行っている8 。保坂（2010）では、日本国内の大学における短 期留学生対象の上級クラスで、映画やドラマを使用した対話を重視した授業実践を試 みている。その結果、留学生のような多言語・多文化学習者は、対話を通じて映画や ドラマから多様な学びを実現していると述べている。また、保坂・三隅（2010）の TV ドラマ『ハケンの品格』を用いた構成主義による授業実践がなされているが、「教室 内でドラマを使うことにより、学習者一人ではできない学びに気づき、ドラマを学習 リソースとして、学びの環境を無意識・意識的に自らが作り出せるようになる」と報 告している。また、対話を重視した授業デザインの実践研究として、対話中心の聴解 授業におけるメディアリテラシーの観点からの学び（保坂 2011）、総合クラスにおけ る対話を中心とした授業デザインによる学び（Gehrtz三隅 2011）、日本国内の大学の 日本事情のクラスにおける学び（門脇 2011a）について報告がなされている。

\section{2 異文化理解のための映像を利用した日本語教育事例}

異文化理解のための映像を利用した日本語教育の実践として、筆者がこれまで取り 組んできた事例を具体的に述べる。事例(1)は外国人留学生を対象にした日本事情クラ

8 平成 23-25 年度科学研究費基盤研究 (C)「映像作品を利用した日本語教育の体系化と授業デザ インの研究」（代表 : 保坂敏子）の共同研究による。 
ス、事例(2)は日本人学生 1 年生を対象にした初年次ゼミ、事例(3)日本人学生 3 年生 のゼミにおける映像作成のプロジェクトである

\section{異文化理解のための日本語教育事例(1)：大学における「日本事情」の授業}

筆者が担当した山口大学（2005-2006 年度）・摂南大学（2009-2012 年度）における 外国人留学生（学部留学生の中上級クラス）を対象にした「日本事情」クラスでは、 映画を利用した授業デザインを試み、教育実践を行っている。

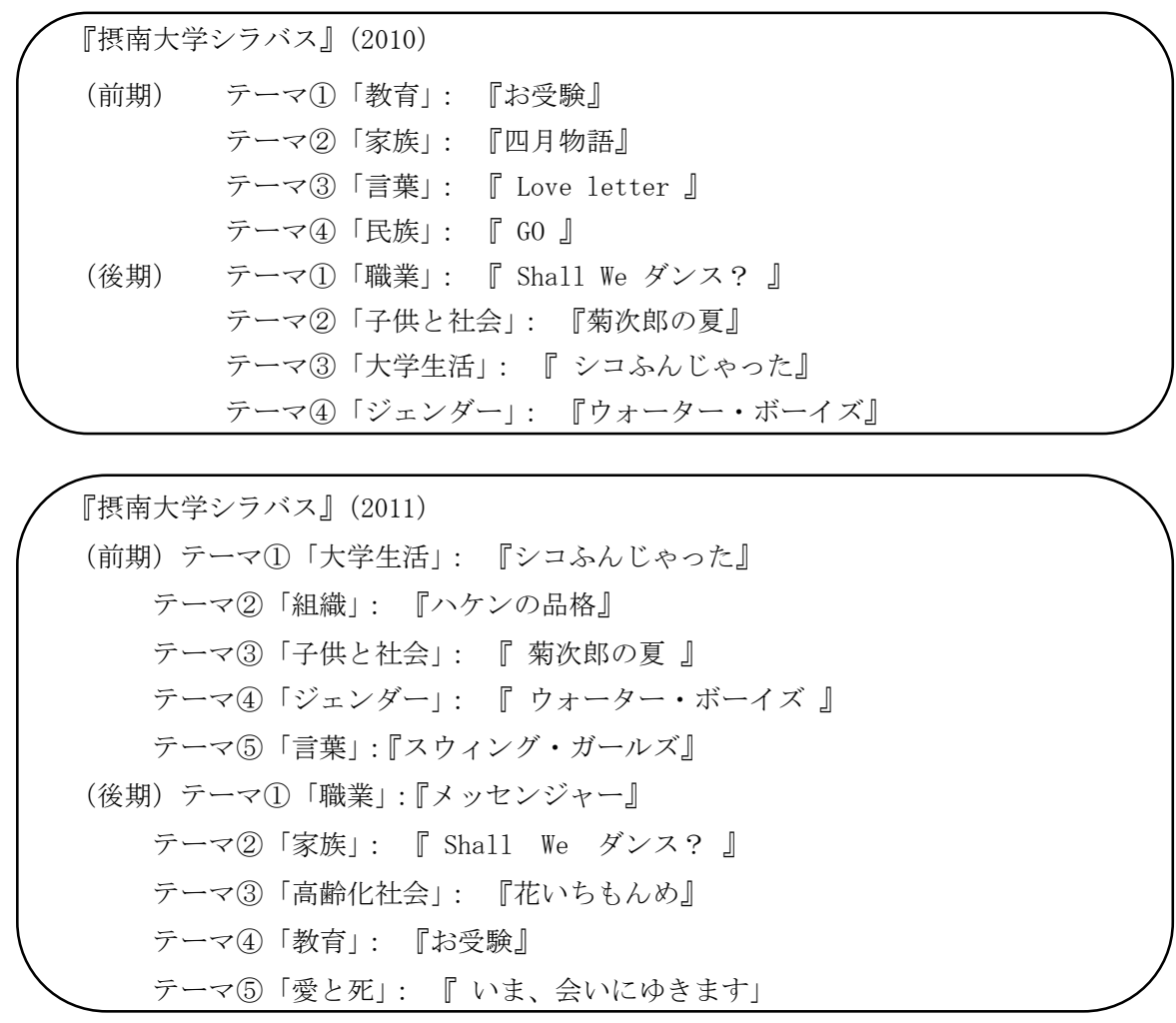

メインテキストは、2010 年度は『映画でジャパニーズ』（窪田編 2004）、2011 年度 は『映画で日本文化を学ぶ人のために』（窪田編 2007）を使用のため、基本的には映 画の選定はこの本で扱われている映画である。これらのメインテキストで、映画につ いての情報・映画の台詞から語彙や表現の解説・文化的な背景について解説するが、 その他に、それぞれの映画に、筆者が作成したタスクシートを用いている。

9 事例(3)映像作品の利用ではなく、映像素材を作成するということを主眼にした。 
1 本の映画を扱うのは 3 コマ（1 コマ90 分）である。時間的な制限もあり、授業で は映像を全て見せるのではなく、場面を選定し部分的に見せており、課題（宿題）と して各自で映画を全部視聴して、レポートを書くことを課している。 全体的な授業の流れは次の通りである。

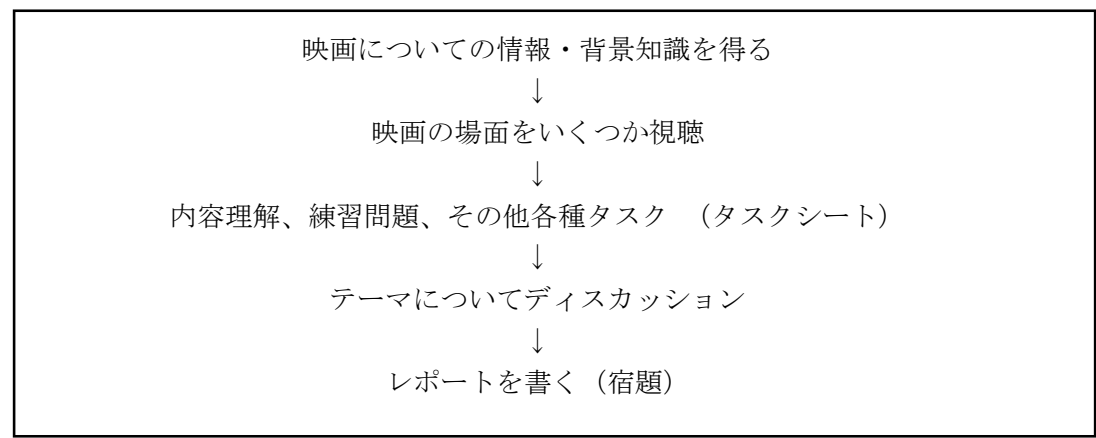

タスクシートは、映画『シコふんじゃった。』の場合は次のようなものである。誌面 の関係で、タスクシートに書き込むスペース、具体的な練習問題（タスク 3 ・タスク 4) は省略する。

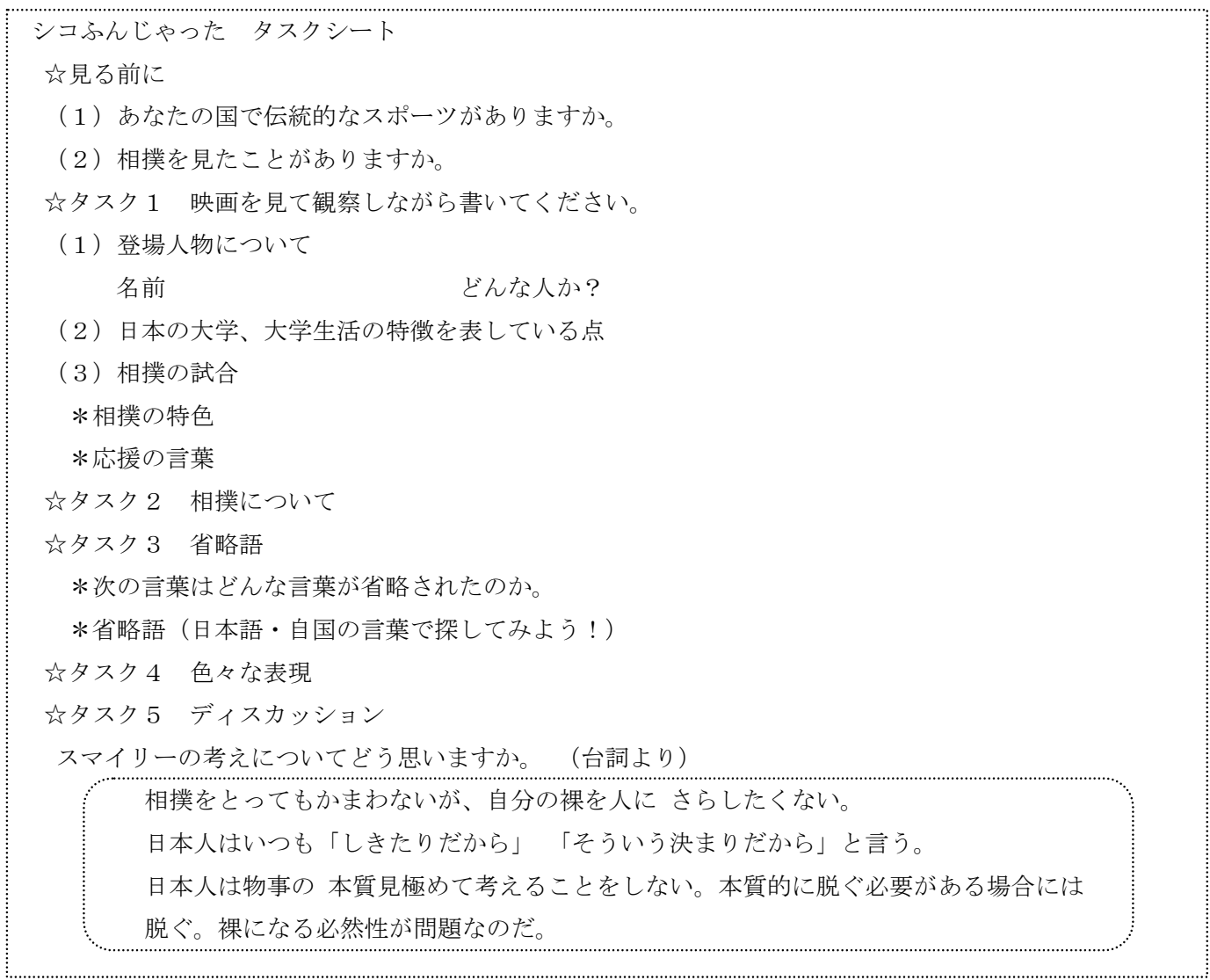


以上のような授業デザインを行い、これまで授業実践を行ってきた。

このような映像作品を利用した日本事情の授業において、どのような学習者の学び があったのかについて考察するために次のような調査分析を行った（門脇 2011a）。分 析データとしたのは 7 本の映画について書かれた学習者のレポート 336 (2 年間 ×計 2 クラス 7 本分）である。学習者のコメントレポートに記述された学習者のコ メントをコード化し、それをカテゴリーにまとめて大きな概念とし、質的に分析した。 コメントをカテゴリー化した結果、「愛・家族の絆」「言語・言語活動」「日本社会・文 化」「人生観」「映画」の6つのカテゴリーにまとめられた。

次に、7 本の映画のうちの映画『お受験』について書かれたレポートを中心に、学 習者のコメントをカテゴリーごとに見ていく。

\section{「愛」「家族」の絆}

小学校のお受験をテーマにしているので、夫婦愛・家族の絆について書かれたコメン トが多かった。夫がリストラされ家事をし、妻が働くというよう夫婦の役割が交替す る場面があり、男女の役割について考えるコメントが見られた。この授業を通してジ エンダーに関する意識が深まったことが窺える。

\section{「言語・言語活動」}

面接試験で子供が正しく敬語を使っている場面より、敬語の大切さについて言及して いるコメントが複数見られた。また、タイトル「お受験」の「お」の意味や機能につ いて意見を述べているものもあった。

日本社会・文化

日本と自国の教育制度や受験の様子、また家庭でのしつけについて比較がなされてい た。授業における対話を通し、同じ国でも地域によって事情が異なり、国が違っても 同じ状況が存在するという気づきが生じており、そこから日本の教育制度に興味を持 ち、更に自主的に調べそこでの考察をレポート発表等に生かしていた。

\section{人生観}

映画の登場人物のように、人生をマラソンに例え「日本での留学生活を最後までがん ばります」という決意を表すコメントが複数あった。このように授業内外での他者と の対話及び自己との対話によって、子供時代を振り返り、自分の人生について新たに 決意するきっかけになっている。

\section{映画}

「授業を通して日本映画に関心が高まった」「日本に住んでいても全てを実体験できる 
わけではないから、映画から多くのことが学べる」という意見があり、授業を通して 映画の見方が変容したことが窺える。

以上、本稿では『お受験』の例のみコメントを挙げたが、映画を視聴して多くの気 付きや学びがあったことがわかる。今後も様々な映像作品をリソースとし、対話を通 した多様な活動をデザインした授業実践を続けていき、そこでの学びについて考察し ていくつもりである。

異文化理解のための「日本語」教育事例(2)：「日本語を客観的に見る」ゼミでの教室活動

摂南大学外国語学部の日本人学生 1 年生 13 名を対象にした 2011 年度後期の「基 礎ゼミナール」の授業科目における教室活動の例を挙げる。基礎ゼミナールは、外国 語学習を楽しみ、2 年生の外国語学習につなげていくことを目的にしている。本ゼミ では外国語としての日本語教育を通し、母語である日本語を客観的に見るという授業 デザインを試みた。部分的に ( 4 コマ分)、TV ドラマの DVD『日本人の知らない日本語』 を利用してディスカッションするという活動を行った。このドラマは、日本語学校に 勤務する日本語教師が主人公で、外国人留学生を対象にした日本語授業や、留学生が 日本で遭遇する異文化体験の場面が出てくる。授業計 4 回の授業のテーマ及びキーワ ードは次のとおりである。

（1）第 $1 \cdot 2$ 話 アルバイト敬語、自己主張、日本在住の外国人日本語学習者

(2) 第 4 話 標準語と共通語、方言、オタク文化

(3) 第 8 話 敬語 コミュニケーションギャップ、茶道、外国人に対する偏見

(4) 第 9 話 若者言葉、曖昧な表現、日本語教師の仕事

上記のテーマについて考察するタスクシートを作成し、毎回自分自身の意見を書い たものを提出させた。学期終了後受講生からは、「自分が使っていたアルバイト敬語の 間違いに気付いた」「改めて日本語について学び考えることができた」「客観的に、外 国人の立場になって考えてみると日本語について理解できないことがある」「外国語を 学ぶより先に日本語を学ぶ必要がある」「授業を通して、同じクラブにいる留学生との コミュニケーションのとき、なぜ伝わらないのか、どうすれば伝わるのかを考えるよ うになった」「これから就職活動をするとき、初対面の人と話すことがある。間違った 日本語を使うと印象が悪くなる。小学校から日本語教育という授業を作ればよい」等 のコメントが得られた。 
日本に住む日本人学生は、「外国人学習者が熱心に日本語を学んでいること」「日本 語教師という仕事」について十分な知識を持っておらず、またこれまで、母語である 日本語について考える機会がほとんどなかった。日本語教育の現場は、異文化間コミ ユニケーションの場そのものである。ドラマの映像で具体的な場面を視聴させること によって、母語である日本語について改めて見つめ直し、日本語教育を学ぶことによ り異文化理解の機会を提供することが可能である。

異文化理解のための日本語教育実践(3):スマホを利用した文化紹介映像作成プロジェクト

摂南大学 3 年生の文化演習 ${ }^{10}$ の科目で、ゼミの学生 7 名を対象にした授業において、 「身近にあるスマートフォンを利用して、学生自ら実際に動画を撮影し、韓国の日本 語教育における「日本事情」紹介のための教材を作成する」というプロジェクトを行 った（門脇 2011b）。そして、作成した映像教材を、韓国の高校における日本語の授業 で使用してもらった。

$<$ 目的 $>$

（1）日本語教授法を学ぶ日本人大学生が、教材作成を通して、外国人学習者を対象 とした「初級日本語」について学ぶ。

( 2 ) 作成した教材を韓国の日本語教育機関で使用してもらい、日韓交流を促進する。 <手順・スケジュール>

3つのグループに分け、グループごとにテーマ・内容を決め、グループでのディスカ ッションを中心に作業を進めていった。

＜全体のスケジュール>2011 年度後期 9 月〜 11 月＼cjkstart計 8 コマ>

\begin{tabular}{|l|l|}
\hline$(1)$ & プロジェクト説明・グループ分け・テーマ選定のためのブレーンストーミング \\
\hline$(2)(3)$ & テーマ決定、撮影内容の検討 \\
\hline (4) (5) & 撮影ロケ \\
\hline (6) (7) (8) & CALL 教室において編集作業・グループごとに発表 \\
\hline
\end{tabular}

$<$ 映像教材内容 $>$

Group 1 摂南大学紹介

Group 2 日本における「韓流」

Group 3 若者の好きなもの
キャンパス案内、授業の様子、韓国人留学生に インタビュー

大阪鶴橋のコリアンタウン、女子中高生インタ ビュー、 K-POP の韓国人店長インタビュー 日本のプリクラ、大阪名物お好み焼き

10 門脇ゼミに配属された日本語教育に関心のある学生を対象にした 3 年生のゼミナール 
$<$ 映像教材の特徴 $>$

学生の視点、若者の視点で対象をとらえて映像化しており、日本語教師が作成する

「日本語教材」とは異なる。技術面で工夫した点は次のとおりである。音声を場面に 応じてアフレコ（編集時に再録音）にした。また、必要なところに日本語字幕をつけ た。BGM には、韓国の人気グループが、日本限定で、日本語で歌っている歌を使用し たり、日本で今年流行している歌も BGM として使用している。映画やドラマのように、 映像の終わりに、制作者・協力者の名前等のテロップが上に流れるように作られてい る。

＜韓国の高校の授業にて日本の大学生の日本事情紹介映像視聴＞

作成した 3 つの映像ファイルを韓国の高校の教員に送付し、韓国の高校 2 年生 32 名対象の日本語クラスにて、日本紹介として使用してもらった。

<プロジェクトの振り返り>

旦本人大学生

よかった点として次のような点が挙げられた。

・動画撮影・編集を初めて経験し、動画に関心を持った。

・簡単な初級レベルの日本語、ティーチャートークでナレーションをつけたり、字 幕をつけたりすることが大変だったが、面白かった。

・ チームで一つの物を作り上げることの大変さを知ることができた。

一方、苦労した点は「街頭でインタビューをお願いして趣旨を伝えること」「人目を 気にしながらの街中での撮影」のように実際に現場での撮影に苦労したようである。

また、韓国人高校生の視聴後のコメントとして良かった点は、「お好み焼きの作り方 がよくわかった」のように映像内容について「韓国人芸能人を誇らしく思えた」のよ うに日本で K-POP が人気あることがわかり韓国文化を見直したという意見、このよう な映像は「めずらしい」というコメントも見られた。

一方、改善点としては「画像が摇れている、字幕を出すのが速い、声が小さい」等 映像撮影や編集の技術面に関すること、「説明不足でよくわからない。インタビューば かりだった」という内容面についても挙げられた。初級学習者のためにナレーション をゆっくり話したことによって、原稿を棒読みしているようにとられたのか「気持ち が入っていない」という厳しいコメントもあった。

今回韓国の高校生のコメントで改善す心゙き点として映像作成の技術面の不十分さが 挙げられた。韓国の高校生は「映像世代」と言われ、映像を見ることに慣れているか 
らであるが、今回日本人学生が作成した映像は、普段テレビ番組で見ているようなプ ロが作成する日本紹介の映像とは異なるものであり、単純に比較する必要はないもの である。高校生が映像を見る前に、どのような観点で映像を見るのかという教師側の 指導がやはり必要である。今回の映像作品は、テレビ番組が作成するステレオタイプ 的な日本紹介ではなく、大学生の生活、大学生個人を伝える、「今」を映すものである。 佐々木（2006）がいう「個の文化」を伝えるための映像であり、これまで日本語教育 で作成された日本語教材とは異なるものである。今回のように身近にあるスマートフ オンを利用した映像作成というのは、簡単で学生が自主的に取り組むことができる。

本実践（事例(3) は「映像を作成すること」を重視したため、韓国の高校の授業で の映像の使い方は韓国人教師に一任した。そのため実際の授業では、映像をただ流し ただけで終わってしまったので、TV番組で見るような映像と比較し、学生が作成し た映像の技術面の未熟さについてのコメントに終始したのだと考えられる。授業で映 像をどのように効果的に使うかというのは、教師の授業デザイン次第である。今回、 映像ファイルを送付するだけでなく、韓日交流の視点から、映像を効果的に利用して、 導入部分やタスク練習及び教室活動を韓国人教師と日本側の教師と協働で考察する必 要がある。

以上、映像を利用した異文化理解の授業実践として、実践事例(1)(2)(3)の授業デザイ ン及びそこでの学習者の学びについて述べた。

\section{6 おわりに}

本稿では、映像作品を利用した異文化理解のための日本語教育について、外国語教 育における先行研究を概観し、海外における映像作品の利用実態について韓国を中心 に述べ、具体的に筆者の教育実践の事例を挙げた。

今後の課題としては、映像作品を利用した異文化理解のための授業実践を積み重ね ていくことである。韓国の日本語教育の夕ならず、海外の日本語教育においてどのよ うに授業実践がなされているか、教師間で意見交換及び情報交換を行い、実践例を収 集していくことにより、授業デザインの理論的な体系化を試みたい。

\section{付記}

韓国における調查でご協力いただいた高校教師研究会及び日本語教育関係者の先生方、 プロジェクト実施にご協力くださった全ての皆様に感謝申し上げます。 


\section{門脇＼cjkstart薰・映像作品を利用した異文化理解のための日本語教育}

\section{参考文献}

鮎澤孝子・加藤清方（1995）『日本語教育における社会言語学的基盤の教育情報化 - 映像素材「とな りのトトロ」を一例として』平成 6 年度科研費報告書

門脇薰（2006）「海外における日本映画の利用について一韓国の日本語教育を中心に一」『日本語教 育学会春季大会予稿集』日本語教育学会

門脇薰（2011a）「映画・ドラマを通した「学び」の可能性(2)一日本事情の授業デザインー」

『異文化コミュニケーションのための日本語 1 』界日本語教育研究大会 2011 高等教育出版社 門脇薰（2011b）「スマートフォンを利用した映像教材の可能性」（発表レジュメ）JTA 設立 10 周年記 念日本語教育研究会 Japanese Teacher Association（韓国：全国日本語教師会）

久保田賢一（2000）『構成主義パラダイムと学習環境デザイン』関西大学出版部

窪田守弘（2002）「映画による日本語教育の実際と可能性」『総合的日本語教育を求めて』国書 刊行会

窪田守弘編（2004）『映画でジャパニーズ』南雲堂フェニックス

窪田守弘編（2007）『映画で日本文化を学ぶ人のために』世界思想社

佐々木倫子（2006）「日本語教育で重視される文化概念」『ことばと文化を結ぶ日本語教育』凡人社 坂根庸子（1998）「映画を使った教材の開発と授業報告一映画『Shall We ダンス?』を用いて」『関 西外国語大学留学生別科日本語教育論集 8』関西外国語大学

塩澤正（2010）「第 1 章 1 節＼cjkstart英語教育でいう文化とは」「第 2 章 1 節 異文化理解とは何か」『英 語教育と文化 一異文化間コミュニケーション能力の養成』大修館書店

下条正純（1995）「中級日本語教育における映画利用例-『シコふんじやった』の場合一」

『AK P 紀要』11 号 同志社大学 AKP 留学生センター

城生伯太郎編 (2002)『映像の言語学』おうふう

新藤照夫（2003）「異文化トレーニングへの映画活用 - カルチュラル・アウェアネスを中心とした一 実践」『映画英語教育論』スクリーンプレイ出版

高瀬文広（1998）「異文化コミュニケーションのための映画題材の利用法の研究 - 『ある愛の詩』を 使用したアメリカ文化分析 『映画英語教育研究』第 4 号 映画英語教育学会

塚越博史（1995）「VTR を利用した EFLにおける異文化理解教育」『映画英語教育の寸すめ』 スクリーンプレイ出版

西隈俊哉（2006）「日本語教育のための映画・アニメの理解と利用」『2006 年度日本語教育学会春 季大会予稿集』日本語教育学会

日本語教育学会（1997）『映画「釣りバカ日誌」を使って』日本語教育学会 
福永保代（1995）「映画を使ったグローバル・エデュケーションの試み」『映画英語教育の寸寸め』 スクリーンプレイ出版

藤森弘子・中村彰（2002）「ビデオを使った聴解授業における現代日本文化事情紹介」『総合的日 本語教育を求めて』国書刊行会

保坂敏子（2010）「対話重視の映画・ドラマを使った日本語教育一多言語・多文化学習者は何を学ぶ か一」『2010 世界日語教育大会論文集』大新書局

保坂敏子・Gehrtz 三隅友子（2010）「ドラマを利用した日本語・日本文化のための教材と授業デザイ ン - 言語と文化の融合をめざして -」日本語教育学会秋季大会ポスター発表資料

牧野成一（2008）「日本語・日本文化教育とアニメー『千と千尋の神隠し』の場合」『外国語として の日本語教育』くろしお出版

宮副ウォン裕子・吉村弓子（2005）「ヴァーチャル教室の『日本の社会・文化』にかかわる意見調 整一日港大学間の電子メール交換活動の実践から」『日本研究と日本語教育におけるグローバルネ ットワーク』book2

八尋春海（2000）『映画で学ぶアメリカ文化』金星堂

梁安玉マギー（2006）「ヴァーチャルの『触れ合い』」『国際間ヴァーチャル教室活動を取り入れた院 生教育研究報告書』桜美林大学大学院

尹福姫（2008）「日本語教育における映画の可能性 - 『映像日本語演習』の例を中心に - 」『人文科 学研究』14 同徳女子大学校

Gehrtz 三隅友子 (2011) 「映画・ドラマを通した「学び」の可能性(3)一対話を中心とした授業デザイ ンー」『異文化コミュニケーションのための日本語 $1 』 世$ 界日本語教育研究大会 2011 高等教育出 版

Fowler, S. M. \& Blohm, J. M. (2004) An analysis of methods for intercultural training. In D. Landis, J. M. Bennett, \& M. J. Bennett (Eds.) Handbook of intercultural training ( $3^{\text {rd }}$ ed.), Thousand Oaks, CA: Sage. 